STUDIA I PRACE WYDZIAŁU NAUK EKONOMICZNYCH I ZARZĄDZANIA nr 41, t. 2

\author{
Maria Parlińska* \\ Łukasz Pietrych** \\ Szkoła Główna Gospodarstwa Wiejskiego w Warszawie
}

\title{
METODA EKSPERYMENTU EKONOMICZNEGO W TEORII STABILNYCH ALOKACJI
}

\begin{abstract}
Streszczenie
W pracy dokonano przeglądu zastosowań metody eksperymentalnej w badaniach ekonomicznych. Jest to metoda odkrywania wiedzy naukowej zdobywająca coraz większe uznanie. Zdefiniowano podstawowe pojęcia z zakresu teorii stabilnych alokacji. Została ona zaczerpnięta $z$ teorii gier i ma bardzo szerokie zastosowanie praktyczne. Badania empiryczne dokonywane w ramach tej teorii są przeprowadzane głównie na podstawie różnego rodzaju eksperymentów ekonomicznych. Szczególnie istotny wkład do teorii dopasowania wniosły prace Alvina E. Rotha. W publikacji podkreślono możliwości badania optymalnych skojarzeń za pomocą eksperymentu.
\end{abstract}

Słowa kluczowe: ekonomia eksperymentalna, teoria stabilnych skojarzeń

\section{Wprowadzenie}

Obecnie dynamicznie rozwijającą się metodą badawczą stosowaną do większości działów i zagadnień, jakie porusza ekonomia, jest metoda eksperymentu. Sam eksperyment, najogólniej ujmując, jest jedną z podstawowych metod zdobywania wiedzy naukowej ${ }^{1}$. Polega na sztucznym wywoływaniu jakiegoś zjawiska, a następnie obserwacji i pomiarach umożliwiających wnioskowanie o jego

* E-mail: maria_parlinska@sggw.pl

** E-mail: lukasz_pietrych@sggw.pl

1 Ekonomia eksperymentalna, red. M. Krawczyk, Wolters Kluwer, Warszawa 2010, s. 9. 
przebiegu i właściwościach. W literaturze można spotkać kilka podziałów eksperymentów ekonomicznych. Jeden z nich zaproponował Roth. Wyszczególnił trzy następujące obszary zastosowania ekonomii eksperymentalnej: eksperymenty testujące hipotezy teorii użyteczności, eksperymenty testujące hipotezy teorii gier, eksperymenty dotyczące różnych form organizacji i struktury rynku² ${ }^{2}$.

Teoria dopasowania jest zaczerpnięta właśnie z teorii gier i ma bardzo szerokie zastosowanie praktyczne. Szczególne uznanie teoria zyskała w 2012 roku, kiedy dwaj amerykańscy naukowcy zostali uhonorowani Nagrodą Banku Szwecji im. Alfreda Nobla w dziedzinie ekonomii za teorię stabilnych alokacji $i$ wykorzystanie projektowania rynku. Prace laureatów miały charakter teoretyczny, a także eksperymentalny. Podstawowe algorytmy z zakresu teorii stabilnych skojarzeń były poprzedzone licznymi badaniami eksperymentalnymi.

Celem pracy jest dokonanie przeglądu zastosowań metody eksperymentalnej w badaniach ekonomicznych. Szczególną uwagę skupiono jednak na badaniach z zakresu teorii stabilnych skojarzeń. Do celów szczegółowych zaliczono omówienie badań eksperymentalnych przeprowadzonych w ramach teorii dopasowania, wskazanie podstawowych wad i zalet stosowania takiej metody, a także wskazanie dalszych możliwości i obszarów badawczych.

\section{Zastosowania eksperymentu w badaniach ekonomicznych}

Ekonomia jeszcze do niedawna była traktowana jako nauka nieeksperymentalna. Stało się tak, ponieważ metoda oparta na eksperymentach nie była uznawana za stosowną w przeprowadzaniu badań na gruncie ekonomiczno-społecznym. Dopiero w drugiej połowie XX wieku eksperyment zaczął być z powodzeniem stosowany i uznawany za metodę badawczą w ekonomii. W tym procesie można wskazać kilka przełomowych momentów, które przyczyniły się do rozpowszechniania ekonomii eksperymentalnej.

Prekursorem badań eksperymentalnych w naukach ekonomicznych był z cała pewnością Chamberlin. Z pomocą studentów przeprowadzał eksperymenty dotyczące teorii równowagi rynkowej. Uczestnicy eksperymentu, podzieleni na dwie grupy, negocjowali ceny zakupu i sprzedaży. Badacz postawił tezę, że sytuacje rynkowe często odbiegają od równowagi teoretycznej zdefiniowanej dla modelu doskonałej konkurencji. Wynikiem eksperymentu było ustalenie przez uczestników ilości rynkowej na większym poziomie niż tej, jaka ukształtowałaby się na rynku konkurencyjnym. Przeciętna cena z kolei kształtowała się na

A.E. Roth, On the Early History of Experimental Economics, „Journal of the History of Economic Thought” 1993, 15, Fall, s. 184-185. 
niższym poziomie niż cena konkurencyjna. Badacz zinterpretował te wyniki jako potwierdzenie swojej hipotezy ${ }^{3}$.

Kontynuatorem tych badań był student Chamberlina i późniejszy laureat Nagrody Nobla w dziedzinie ekonomii - Vernon Smith. Przy wykorzystaniu tej metody badawczej w latach 60 . badał aukcje dwustronne. Eksperyment był oparty na następujących założeniach: sprzedający mieli wyznaczoną cenę minimalną, po jakiej mogli sprzedać dane dobro, oraz kupujący mieli wyznaczoną cenę maksymalną, po jakiej mogli kupić oferowane dobro. Badacz stwierdził, że taki mechanizm prowadzi do szybkiej i efektywnej wymiany'. W 2002 roku wraz z Danielem Kahnemanem otrzymali Nagrodę Nobla za dokonania w dziedzinie ekonomii eksperymentalnej i behawioralnej. Smith opracował podstawy metodologiczne tej metody badawczej. Wyniki rozważań przedstawił w Economics in the Laboratory. Wyróżnił trzy czynniki, które składają się na eksperyment ekonomiczny: środowisko, instytucje, zachowanie ${ }^{5}$.

Ważnym wkładem Smitha w metodologię badań eksperymentalnych było również opracowanie teorii wartości narzuconej, która zakładała wprowadzenie wynagrodzenia pieniężnego adekwatnego do podejmowanych decyzji oraz kontroli nad preferencjami uczestników eksperymentu. Szczególnie ta druga zasada przyczyniła się w znaczący sposób do zwiększenia wiarygodności eksperymentów ${ }^{6}$.

Równolegle nastąpił rozwój eksperymentów o tematyce gier strategicznych. Badania w tym obszarze były zdeterminowane sytuacją polityczną, a mianowicie stanem zimnej wojny. Ośrodkiem, gdzie realizowano tego typu projekty, był Rand Corporation, organizacja z bardzo dużym wkładem w naukę, w której pracował m.in. ekonomista Kenneth Arrow. W Europie pierwsze eksperymenty na początku lat 70. XX wieku przeprowadzał Reinhard Selten (Nagroda Nobla w 1994). Zajmował się badaniami nad oligopolami. Projektował liczne eksperymenty z małymi rynkami, oligopolami, a także oparte na tworzeniu koalicji. W swoich eksperymentach zwracał uwagę na zalety opracowywania strategii na każdy możliwy w danej grze wariant. Pozwalało to na lepsze zrozumienie motywów postępowania graczy ${ }^{7}$.

3 E. Jabłońska, Obszary zastosowania ekonomii eksperymentalnej, w: Problemy współczesnej ekonomii, red. B. Kryk, D. Miłaszewicz, Studia i Prace Wydziału Nauk Ekonomicznych i Zarządzania nr 32, t. 2, Wydawnictwo Naukowe Uniwersytetu Szczecińskiego, Szczecin 2013, s. 47.

4 P. Pońsko, Vernon Smith, „Decyzje” 2008, nr 10, s. 124.

5 V. Smith, Economics in the laboratory, „Journal of Economic Perspectives” 1994, vol. 8, nr 1, s. 113.

6 P. Pońsko, Vernon Smith..., s. 126.

7 M. Malawski, Reinhard Selten, „Decyzje” 2005, nr 4, s. 78. 
Duży wpływ na rozwój metody eksperymentalnej miało wyodrębnienie się teorii gier jako dziedziny nauki. Eksperymenty teoriogrowe mają na celu badanie zachowań ludzi $\mathrm{w}$ interakcji $\mathrm{z}$ decyzjami, jakie podejmują pozostali współgracze. Podstawowym założeniem takich badań jest to, że gracze są racjonalnymi egoistami, czyli dążą do maksymalizacji własnej funkcji użyteczności. Założenie to jest jednak dość wątpliwe, gdyż badania pokazują, że ludzie jako podmioty niemające dostępu do pełnej i bezpłatnej informacji nie są zdolni do doskonałej racjonalności. Z uwagi na tego typu ograniczenia coraz większe uznanie zdobywa tzw. behawioralna teoria gier, dzięki której do analizy możliwe jest wprowadzenie takich czynników, jak emocje, moralność, błędy poznawcze i obliczeniowe, ograniczone możliwości tworzenia strategii i budowania prognoz, niepewność co do racjonalności pozostałych graczy oraz możliwość uczenia się przez uczestników gry ${ }^{8}$.

Bardzo duży wkład w rozwój ekonomii eksperymentalnej miały również eksperymenty z zakresy teorii podejmowania decyzji indywidualnych. Należy tutaj przede wszystkim wymienić tzw. paradoks Allaisa falsyfikujący założenia teorii oczekiwanej użyteczności von Neumanna i Morgensterna. Francuski ekonomista Maurice Allais w 1953 roku przeprowadził eksperyment, podczas którego uczestnicy zostali poproszeni o dokonanie wyboru pomiędzy dwiema możliwościami. Każdy wariant z kolei był loterią złożoną z możliwych wygranych dla pewnego, ustalonego poziomu prawdopodobieństwa. Wyniki eksperymentu wykazały, że nie zawsze jednostki wybierające alternatywę dającą pewność wygranej (osoby unikające ryzyka) konsekwentnie dokonują takiego wyboru (ich decyzje zależą od rozkładu prawdopodobieństwa zmiennej losowej, jaką stanowi wysokość wygranej).

Wnioski przeczące teorii oczekiwanej użyteczności sformułowali również Daniel Kahneman i Amos Tversky. W latach 70. XX wieku opracowali własną teorię (teoria perspektywy), na podstawie której stwierdzili, że wartość perspektywy osiągnięcia danego wyniku zależy od dwóch czynników: prawdopodobieństwa wygranej oraz subiektywnej oceny użyteczności konkretnej wygranej9.

\section{Teoria stabilnych skojarzeń}

W latach 60. XX wieku David Gale oraz Lloyd Shapley podjęli w badaniach tematykę stabilnych skojarzeń, których efektem było opracowanie algorytmu

\footnotetext{
8 A. Kosior, Modele nieegoistycznych preferencji: wprowadzenie i najnowsze badania, „Decyzje” 2008, nr 9, s. 6.

9 E. Jabłońska, Obszary zastosowania..., s. 41-42.
} 
Gale'a-Shapleya gwarantującego optymalną alokację. Powodem zainteresowania się tym zagadnieniem był problem, z jakim borykały się uczelnie amerykańskie. Dotyczył rekrutacji kandydatów na uczelnie. Celem prac Gale’a i Shapleya było opracowanie systemu rekrutacji, który dopasowałby kandydatów do uczelni w taki sposób, że oczekiwania zarówno jednej strony, jak i drugiej byłyby uwzględnione w jak największym stopniu. Oznacza to, że kandydat dostanie się do preferowanej uczelni, natomiast uczelnia będzie miała studentów z największą liczbą punktów. Ważne było również, aby system był prosty i pozbawiony niepewności, która była ściśle związana $\mathrm{z}$ poprzednim systemem rekrutacji i towarzyszyła obydwu stronom biorącym udział w procesie. Efektem ich pracy był opublikowany w 1962 roku artykuł College admissions and the stability of marriage. Autorzy przedstawili w nim model procesu rekrutacji i wprowadzili pojęcie optymalnego dopasowania kandydatów do szkół. Dodatkowo dowiedli, że zawsze istnieje dokładnie jeden przydział optymalny ${ }^{10}$.

Teoria Gale'a-Shapleya znalazła zastosowanie do modelowania wielu zjawisk ekonomicznych i społecznych. Na praktycznych zastosowaniach algorytmu skupił się w swoich badaniach Alvin E. Roth ${ }^{11}$. Koncentrował się głównie na dwóch dziedzinach: systemie edukacji i systemie zdrowotnym. W tym celu organizował eksperymenty negocjacyjne. Jeden zbiór stanowili lekarze, którzy chcieli się zatrudnić w szpitalach. W drugim szpitale, które chciały zatrudnić lekarzy. Szpital miał pewne preferencje wśród lekarzy, lekarze wśród szpitali. Chodziło o to, żeby jak najlepiej dopasować jednych do drugich. W kolejnych latach zostały wdrożone programy oparte na doskonalszych algorytmach, testowane i obejmujące wciąż nowe obszary. Wyzwaniem stała się stabilność alokacji w zmieniających się strukturach rynkowych. Należy tutaj przede wszystkim wspomnieć o działalności Narodowego Programu Alokacji Personelu (NRMP - National Resident Matching Program) - organizacji pozarządowej i non profit powołanej w Stanach Zjednoczonych do życia w 1952 roku w celu niesienia pomocy absolwentom szkół medycznych w dostępie do mieszkań oraz staży w szpitalach (uwzględniając również potrzeby współmałżonków) ${ }^{12}$.

10 Z. Świtalski, O kojarzeniu małżenstw i rekrutacji kandydatów do szkót, „Wiadomości Matematyczne”, Seria 2, R. 44, 2008, s. 37.

11 A.E. Roth, The Evolution of the Labor Market for Medical Interns and Residents: A Case Study in Game Theory, „Journal of Political Economy” 1984, nr 92, s. 991-1016; A.E. Roth, M.A. Sotomayor, Two-sided matching. A study in game theoretic modeling and analysis, 1992, http://web.stanford.edu/ alroth/papers/92_HGT_Two-SidedMatching.pdf [dostęp 10.01.2015]; A.E. Roth, The economist as engineer: game theory, experimentation, and computation as tools for design economics, „Econometrica” 2002, vol. 70, $\mathrm{nr} 4$, s. $1341-1378$.

12 W. Stankiewicz, Kolejny sukces teorii gier: nobliści z ekonomii 2012, „Ekonomia i Prawo” 2013, t. 12, nr 1, s. $176-178$. 
Przełomowym osiągnięciem była próba wdrożenia tzw. przyjaznej wymiany (exchange ,in kind”). Była to struktura organizacyjna rynku wymiany nerek (działająca na terytorium Nowej Anglii). Opracowany algorytm uwzględniał nie tylko więzi między parami (dawca-biorca), lecz także ich następstwa - łańcuchy równoczesnych operacji chirurgicznych. Roth wynalazł sposób rozwiązania problemu, który ma miejsce gdy osoba nie może oddać nerki swojemu krewnemu, np. ze względu na niezgodność grup krwi. Autor zaproponował rozwiązanie oparte na teorii stabilnego dostosowania. Algorytm Rotha umożliwia skojarzenie z inną parą osób z takim samym problemem, która może wymienić się „,krzyżowo" nerkami z tą pierwszą. Przeprowadza się w takim przypadku równolegle cztery operacje. Autor część badań oparł na eksperymentach, empirycznie badając różne rozwiązania.

Od momentu opublikowania artykułu College admissions and the stability of marriage prace nad tym algorytmem znacznie się posunęły. Zaczęto analizować własności oraz różnego rodzaju uogólnienia algorytmu, strukturę zbioru skojarzeń stabilnych oraz ich liczbę. Stwierdzono, że jedną z ważnych własności tego modelu jest tzw. niemanipulowalność. Szczególnie jest ona ważna w procesach rekrutacji, gdyż nie pozwala uczestnikom na fałszowanie swoich preferencji. Dodatkowo należy stwierdzić, że ta własność jest również bardzo ważna już na poziomie badań eksperymentalnych (niektórzy z uczestników mogliby podawać nieprawdziwe preferencje po to, aby znaleźć się w lepszej sytuacji, zdobyć większą wypłatę).

W Polsce jak do tej pory badania dotyczące teorii stabilnych alokacji koncentrują się głównie na zagadnieniach teoretycznych obejmujących analizę własności podstawowego modelu Gale'a-Shapleya (GS), szukanie jego powiązań z różnymi działami matematyki, analizę różnych modyfikacji algorytmu GS (ewentualnie alternatywnych algorytmów prowadzących do skojarzeń stabilnych) oraz analizę różnych uogólnień podstawowego modelu GS (np. są modyfikowane założenia o preferencjach, limitach itd.) $)^{13}$.

\section{Podsumowanie}

Jednym z podstawowych aspektów, na którym była oparta krytyka metody eksperymentalnej, jest to, że w badaniach uczestniczą najczęściej studenci. Jest to

13 Z. Świtalski, Równowagi na rynkach z dwustronnymi preferencjami, „Przegląd Statystyczny”, R. 57, z. 4, 2010, s. 54-69; M. Anholcer, W. Dymowski, M. Godlewski, Optymalny przydziat studentów do specjalności jako wariant zagadnienia doboru małżeństw, w: Metody i zastosowania badań operacyjnych, red. A. Całczyński, Prace Naukowe Politechniki Radomskiej, Radom, 2003, s. 31-42. 
dość specyficzna grupa badawcza, a ich decyzje nie zawsze mogą odzwierciedlać prawdziwe wybory uczestników rynku. Dlatego proponuje się, aby w badaniach nie uczestniczyły losowo lub przypadkowo wybrane osoby, lecz osoby związane ze środowiskiem, którego dotyczy przeprowadzany eksperyment. Jednak, jak zauważa Krawczyk, zazwyczaj celem eksperymentu nie jest zmierzenie poziomu zmiennej w populacji, lecz rozpoznanie kierunku wpływu pewnego sztucznie wywołanego impulsu ${ }^{14}$. Eksperymenty przeprowadzane przez najważniejszego badacza teorii dopasowania były dokonane przede wszystkim na jednostkach ściśle związanych ze sformułowanym problemem badawczym (z jednej strony lekarze, a z drugiej zarządzający szpitalami).

Innym z kolei zarzutem stawianym eksperymentom ekonomicznym jest to, że rynek stworzony w warunkach laboratoryjnych jest zbyt ,sterylny” oraz stanowi daleko idące uogólnienie realnych sytuacji i problemów decyzyjnych. Na prawdziwym rynku może zaistnieć wiele czynników o charakterze zarówno ekonomicznym, jak i psychologicznym, które w istotny sposób mogą oddziaływać na decydenta. Jak już wcześniej wspomniano, dla eksperymentów teoriogrowych przyjmuje się założenie o dążeniu do maksymalizacji funkcji użyteczności przez ich uczestników. Również w badaniach eksperymentalnych z zakresu teorii dopasowania zakłada się, że każdy uczestnik dokonuje uporządkowania elementów ze zbioru przeciwnego według preferencji i pożąda najbardziej preferowanego przez siebie skojarzenia.

Jednym z poważnych problemów, jaki się tu rysuje, jest także sposób określania tych preferencji. Wszyscy uczestnicy gry z każdej ze stron (przykładowo pracownicy) powinni przyjąć ujednolicony system kreowania swoich preferencji, czyli jednolite kryteria wyboru. W praktyce to założenie jest dość trudne do spełnienia, jak wiadomo, różni pracodawcy w procesie wyboru pracownika kierują się różnymi kryteriami. Dla jednych ważniejsze jest doświadczenie, dla innych z kolei wykształcenie czy takie cechy, jak szybkość uczenia się, punktualność itp. Podobna sytuacja ma miejsce po stronie pracowników, dla jednych ważniejsze są kryteria ekonomiczne, dla innych prestiż. Należy także pamiętać o braku całkowitej racjonalności uczestników badania, a tym samym niepełnej informacji o problemie decyzyjnym. Istnieje zatem konieczność określenia systemu, który w jednoznaczny i porównywalny sposób umożliwiałby hierarchizację wszystkich elementów z przeciwnego zbioru.

Teoria stabilnych skojarzeń w istotny sposób przyczyniła się do udoskonalania istniejących, a także tworzenia nowych, efektywniejszych systemów rekrutacji. Należy stwierdzić, że istnieje silna potrzeba praktycznych badań na tym gruncie,

14 Ekonomia eksperymentalna..., s. 58. 
a metoda eksperymentu ekonomicznego przy zachowaniu niezbędnych zasad metodologicznych znajduje w tym przypadku zastosowanie.

\section{Literatura}

Anholcer M., Dymowski W., Godlewski M., Optymalny przydziat studentów do specjalności jako wariant zagadnienia doboru malżeństw, w: Metody i zastosowania badań operacyjnych, red. A. Całczyński, Prace Naukowe Politechniki Radomskiej, Radom 2003.

Ekonomia eksperymentalna, red. M. Krawczyk, Wolters Kluwer, Warszawa 2010.

Jabłońska E., Obszary zastosowania ekonomii eksperymentalnej, w: Problemy wspótczesnej ekonomii, red. B. Kryk, D. Miłaszewicz, Studia i Prace Wydziału Nauk Ekonomicznych i Zarządzania nr 32, t. 2, Wydawnictwo Naukowe Uniwersytetu Szczecińskiego, Szczecin 2013.

Kosior A., Modele nieegoistycznych preferencji: wprowadzenie i najnowsze badania, „Decyzje” 2008, nr 9.

Malawski M., Reinhard Selten, „Decyzje” 2005, nr 4.

Pońsko P., Vernon Smith, „Decyzje” 2008, nr 10.

Roth A.E., On the Early History of Experimental Economics, ,Journal of the History of Economic Thought" 1993, 15, Fall.

Roth A.E., The economist as engineer: game theory, experimentation, and computation as to ols for design economics, „Econometrica” 2002, vol. 70, $\mathrm{nr} 4$.

Roth A.E., The Evolution of the Labor Market for Medical Interns and Residents: A Case Study in Game Theory, „Journal of Political Economy” 1984, nr 92.

Roth A.E., Sotomayor M.A., Two-sided matching. A study in game theoretic modeling and analysis, 1992, http://web.stanford.edu/ alroth/papers/92_HGT_Two-SidedMatching.pdf.

Shapley L.S., Gale D., College admissions and the stability of marriage, „The American Mathematical Monthly" 1962, vol. 69.

Smith V., Economics in the laboratory, „Journal of Economic Perspectives” 1994, vol. 8, nr 1.

Stankiewicz W., Kolejny sukces teorii gier: nobliści z ekonomii 2012, „Ekonomia i Prawo" 2013, t. 12, nr 1.

Świtalski Z., O kojarzeniu małżeństw i rekrutacji kandydatów do szkót, „Wiadomości Matematyczne", Seria 2, R. 44, 2008.

Świtalski Z., Równowagi na rynkach z dwustronnymi preferencjam i, „Przegląd Statystyczny", R. 57, z. 4, 2010. 


\title{
METHOD OF ECONOMIC EXPERIMENT IN THE THEORY OF STABLE ASSOCIATIONS
}

\begin{abstract}
The paper is a review of the use of experimental methods in economic research. It is a method, appreciated by scientists more and more, and discovering new scientific knowledge. In the next part it is defined the basic concepts of the theory of stable associations, which was taken from game theory and have a very wide practical applications. Empirical studies are conducted mainly on the basis of various economic experiments. Especially important contribution to the theory of matched made AE Roth works. The publication highlighted the potential optimal research associations through experiment.
\end{abstract}

Translated by Maria Parlińska, Lukasz Pietrych

Keywords: experimental economics, the theory of stable associations

JEL code: C99 
